\title{
Agrobacterium tumefaciens-mediated Transformation of Jatropha curcas: Factors Affecting Transient Transformation Efficiency and Morphology Analysis of Transgenic Calli
}

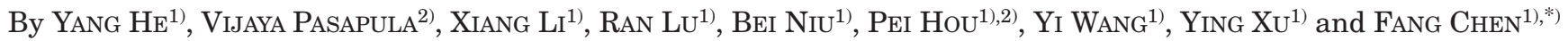

(Received $17^{\text {th }}$ February 2008)

\begin{abstract}
An efficient system for Agrobacterium tumefaciensmediated transformation of Jatropha curcas was developed in this study. Several factors affecting the transformation efficiency were optimized, including the explant type, preculture and coculture periods, usage of acetosyringone and density of $A$. tumefaciens. Compared with other explants, 2-day precultured and cocultured hypocotyl explants showed a significant GUS transient expression efficiency $(67.7 \%)$. Moreover, adding AS showed a remarkable increase in transformation efficiency. After infecting with A. tumefaciens, hypocotyl explants were subjected to expansion and proliferation on MS medium with $1.0 \mathrm{mg} \cdot \mathrm{l}^{-1}$ IBA and $0.5 \mathrm{mg} \cdot \mathrm{l}^{-1} \mathrm{BA}$. Transformants were demonstrated by the GUS assay and PCR analysis. Rate of hypocotyl explants forming resistant calli reached $67.08 \%$. Furthermore, in the transformed calli development, morphologic changes (calli superficial development and internal structure) were observed by SEM and LM. The present study has provided a fundamental information and research approach for the future study of inducing new traits to $J$. curcas and genetic modification.
\end{abstract}

Key words: Jatropha curcas, Agrobacterium tumefaciens-mediated transformation, light microscopy, scanning electron microscopy.

Abbreviation: AS, Acetosyringone; BA, Benzylaminopurine; GUS, beta-glucuronidase; IBA, Indole-3-butyric acid; LM, light microscopy; MS, Murashige and Skoog medium; nos, nopaline synthase; NPTII, Neomycin phosphotransferase; SEM, scanning electron microscopy; X-Gluc, 5-bromo-4-chloro-3-indolylbeta-D-glucuronide.

\section{Introduction}

Jatropha curcas L., belonging to the family Euphorbiaceae, is widely distributed in tropical and subtropical areas (ScHMOOK et al., 1997). As a multi-purpose tree, it has a long history in reclaiming land and making feedstuff, soap, cosmetics, pesticide, anti-cancerous, antiviral and anti-fungal medicine, and other traditional Chinese medicine (STAUBMANn et al., 1999; OpEnshaW, 2000; LiN et al., 2004; MAMPANE et al., 2006; HUANG et al., 2008). Recently, J. curcas has drawn increased attention for its high seed oil content (50 60\%), which exceeds seed oil content of other biodiesel plants such as

\footnotetext{
1) Key Lab of Bio-resources and Eco-environment, Ministry of Education, College of Life Sciences, Sichuan University, Chengdu 610064, People's Republic of China.

$\left.{ }^{2}\right)$ Department of Biological Sciences, Texas Tech University, Lubbock TX 79409, USA.

*) Author for correspondence: FANG CHEN. Fax: +86-28-85417281. E-Mail: biochenfang@@yahoo.cn
}

cole and soybean. Furthermore, some traits for seed oil from J. curcas, high-oleate and low-linolenate, can increase oil stability and reduce the requirement of catalytic hydrogenation in industrial process. These merits make J. curcas be very promising as an energy plant. However, the development of J. curcas biodiesel industrialization was restricted because of its lower yield and limited growth areas. As an oil-producing tree, J. curcas still requires significant genetic improvement in order to gain new traits, such as high-yield and freeze-resistant characteristics. Therefore, an efficient transgenic system for J. curcas will provide a new research approach for its potential to be fully realized.

In recent years, regenerations of different explants from J. curcas have been reported (SUJATHA et al., 1996; SARDANA et al., 2000; WEI et al., 2004; RAJORE et al., 2005; Hou et al., 2006; SUJATHA et al., 2006; JHA et al., 2007; Shrivastava and BANERJEe, 2008). On the base of regenerations of different explants, we have paid more attention to $A$. tumefaciens-based genetic transformation of J. curcas. Li et al. (2008) reported the A. tumefaciens-mediated cotyledon disc transformation method. However, to date, no report showed an optimized system for A. tumefaciens-mediated transformation using hypocotyl of J. curcas. Furthermore, no report showed morphology analysis of transgenic calli development in J. curcas.

In this paper, we are trying to report a stable and efficient transformation system using hypocotyl explants of J. curcas. Several factors, including explant types, preculture and coculture period, usage of AS and density of A. tumefaciens, were optimized. Using this system, transformed calli have been successfully achieved. In transformed calli development, morphologic characteristics (superficial development and internal structure of transformed calli) were observed by LM and SEM. This study provides fundamental information for the future study of genetic modification in J. curcas.

\section{Materials and Methods}

\section{Plant materials, culture media, and culture conditions}

The seeds of J. curcas were collected from Panzhihua city, Sichuan province, P. R. China. Mature seeds were decoated and rinsed in running tap water for $30 \mathrm{~min}$. The decoated seeds were surface-sterilized in $70 \%(\mathrm{v} / \mathrm{v})$ ethanol for $30 \mathrm{~s}$, in $0.1 \%(\mathrm{w} / \mathrm{v}) \mathrm{HgCl}_{2}$ for $15 \mathrm{~min}$, and finally rinsed five times with sterile water. The embryo axes and papery cotyledons were excised and implanted on MS (Murashige and Skoog, 1962) medium. 15-dayold seedlings were used as explant source in the trans- 
formation experiments. Calli induction medium was MS medium containing $1.0 \mathrm{mg} \cdot \mathrm{l}^{-1} \mathrm{IBA}$ and $0.5 \mathrm{mg} \cdot \mathrm{l}^{-1} \mathrm{BA}$. All culture media were supplemented with $3 \%(\mathrm{w} / \mathrm{v})$ sucrose, adjusted to $\mathrm{pH} 5.8$ prior to the addition of $0.8 \%$ (w/v) agar and autoclaved at $121^{\circ} \mathrm{C}$ and 15 psi for $20 \mathrm{~min}$. Antibiotics used for removal of A. tumefaciens or selection of transformed cells were filter-sterilized and added to the autoclaved media after the media had cooled to about $45^{\circ} \mathrm{C}$. The cultures were maintained at $26 \pm 2{ }^{\circ} \mathrm{C}$ under the cycle of $16 \mathrm{~h}$ light and $8 \mathrm{~h}$ dark with a light intensity of $90 \mu \mathrm{mol} \mathrm{m} \mathrm{m}^{-2} \mathrm{~s}^{-1}$ provided by fluorescent lamps.

\section{Bacterial strains and plasmid}

Agrobacterium tumefaciens strain EHA105 (HooD et al., 1993) containing the binary plasmid pBI121 was used in the transformation experiments. The plasmid pBI121 carries the NPTII gene and GUS gene. The NPTII gene is under the control of the nos promoter and the terminator from nos which provides polyadenylation signal. The NPTII gene confers kanamycin resistance. The GUS activity is under the control of the cauliflower mosaic virus $35 \mathrm{~S}$ promoter and the terminator from nos provides polyadenylation.

\section{Tolerance of explants to kanamycin}

Hypocotyl explants were plated on calli induction medium supplemented with $0,20,40,60,80$, and 100 $\mathrm{mg} \cdot \mathrm{l}^{-1}$ of kanamycin to test their tolerance. Ten plates (four explants per plate) were cultured for each of the six levels of kanamycin.

\section{Coculture, removal of A. tumefaciens and selection of transformants}

A single bacterial colony was inoculated into $50 \mathrm{ml}$ liquid YEB (SAMBROOK et al., 1989) containing $50 \mathrm{mg} \cdot \mathrm{l}^{-1}$ each of streptomycin, kanamycin, and rifampicin and grown overnight at $28^{\circ} \mathrm{C}$ on a shaker at $180 \mathrm{rpm} .2 \mathrm{ml}$ overnight culture was re-inoculated into $20 \mathrm{ml}$ fresh YEB medium containing the same antibiotics and grown overnight. Bacteria were pelleted at $4,000 \mathrm{rpm}$ for 10 min and resuspended in $20 \mathrm{ml}$ liquid $\mathrm{MS}$ medium ( $\mathrm{PH}$ 7.0) with $100 \mu \mathrm{M}$ AS (or not adding AS), and agitated (180 rpm) in a shaking incubator at $25^{\circ} \mathrm{C}$ for $30 \mathrm{~min}$ before inoculation. About $0.5 \mathrm{~cm}$ hypocotyl segments were excised from individual 15-day-old seedlings and precultured $(0,2,4,6$ days) on calli induction medium prior to infection with A. tumefaciens. The precultured hypocotyl explants were immersed in $20 \mathrm{ml}$ bacterial suspension of OD600 $=0.6$ densities for $10 \mathrm{~min}$ respectively. Then the hypocotyl explants were blotted dry on sterile filter paper and cocultivated $(0,2,4,6$ days) in calli induction medium at $26 \pm 2{ }^{\circ} \mathrm{C}$. Subsequently, cocultivated explants were transferred to new calli induction medium including $500 \mathrm{mg} \cdot \mathrm{l}^{-1}$ cefotaximate and 40 $\mathrm{mg} \cdot \mathrm{l}^{-1}$ kanamycin (designated selective medium) for selecting.

\section{Preparation of samples for LM and SEM}

Callus tissue was cut into $3 \mu \mathrm{m}$ thickness by using freezing microtome and viewed in Olympus BH-2 LM.
For SEM, small pieces of tissue $(3-5 \mathrm{~mm})$ were collected and fixed in 10:5:85 (v/v) FAA (formalin : acetic acid : $94 \%(\mathrm{v} / \mathrm{v})$ ethanol). The fixed tissues were dehydrated in an ethanol series, infiltrated with 1:1 (v/v) Historesin: $95 \%(\mathrm{v} / \mathrm{v})$ ethanol, substituted in pure acetone and embedded in isoamyl acetate, dried with a critical point dryer, covered with gold, and viewed in a scanning electron microscope.

\section{Histochemical detection of GUS expression}

GUS histochemical assay was performed according to the method from JEFFERSON et al. (1987). The plant materials were stained with $1 \mathrm{mM}$ X-Gluc in a $\mathrm{pH} 7.0$ phosphate buffer (100 mM primary sodium phosphate) containing $10 \mathrm{mM}$ EDTA, $0.5 \mathrm{mM}$ potassium ferricyanide, $0.5 \mathrm{mM}$ potassium ferrocyanide, and $0.1 \%(\mathrm{v} / \mathrm{v})$ Triton X-100 at $37^{\circ} \mathrm{C}$ overnight. After staining, chlorophyll was cleared by soaking the plant materials in $95 \%$ $(\mathrm{v} / \mathrm{v})$ ethanol.

\section{Genomic DNA isolation, PCR analyses}

Genomic DNA was isolated from the putative transformants and untransformed control calli by CTAB method (SANGHAI-MAROOF et al., 1984). NPTII gene was used as a selectable marker, primers for amplification of NPTII gene, forward primer (5'-ACAACAGACAATCGGCTG-3'), reverse primer (5'AAGAACTCGTCAAGAAGGCG-3'), were designed. A total of 100-300 ng genomic DNA was used as template. PCR was conducted as follows: denaturation at $94^{\circ} \mathrm{C}$ for $5 \mathrm{~min}, 30$ cycles at $94^{\circ} \mathrm{C}$ for $40 \mathrm{~s}$, $50^{\circ} \mathrm{C}$ for $1 \mathrm{~min}$ and $72^{\circ} \mathrm{C}$ for $1.5 \mathrm{~min}$, and then $72^{\circ} \mathrm{C}$ for $10 \mathrm{~min}$. The amplified bands were subjected to a $1 \%$ agarose gel electrophoresis, and observed under UV light.

\section{Statistical analysis}

All the experiments were laid out in completely randomized design with three repetitions. The GUS transient expression efficiency was presented as mean \pm standard error. The statistical significance of differences between means was estimated at the $5 \%$ significance level by the t test.

\section{Results and Discussions}

In order to improve the efficient transformation system of J. curcas, some factors affecting transformation were optimized.

\section{Effect of explant types and $A S$}

As shown in Figure 1, different explant types from $J$. curcas exhibited a significant difference in transformation efficiency. Compared with other explants, hypocotyl showed the highest GUS transient expression efficiency (42.3\% without AS or $67.7 \%$ with AS). The reason was yet unknown. Maybe there was a difference in component or wound response between hypocotyl and other explants, resulting in a difference in bacterial binding or activation of vir genes.

AS produced in wound response of plant cells, a phenolic compound, can induce the transcription of the viru- 


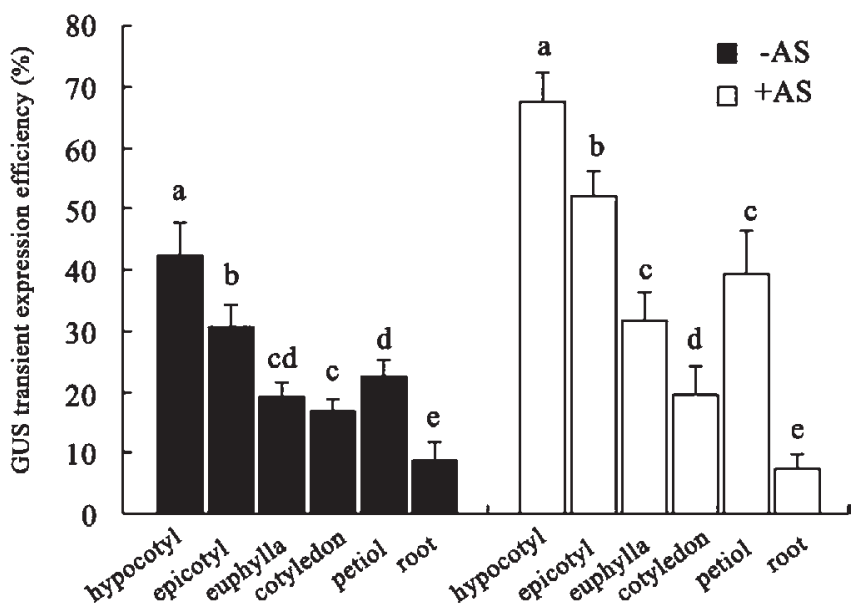

Explant source

Figure 1. - Effect of explants type and AS on GUS transient expression efficiency. Bar represents mean \pm standard error of three replicates. The GUS transient expression efficiency was defined as the number of explants producing GUS-positive blue spots as the percentage of the total number of explants. Positions with different letters above bars represent values followed by the same letters are not significantly different from each other by $\mathrm{t}(P=0.05)$ test.

lence genes of A. tumefaciens (SHARMA et al., 2005) to increase transformation efficiency. Many reports showed that AS could remarkably improve the transformation efficiency in some plants, such as apple (JAMES et al., 1993), rice (HIEI et al., 1994), and maize (IsHIDA et al., 1996). However, a study from Godwin et al. (1991) suggested that adding AS could suppress virulence of some A. tumefaciens strains. In this experiment, adding AS enhanced obviously GUS transient expression efficiency (the highest increment was up to $25 \%$ ) in explants (except for root) (Fig. 1).

\section{Effect of preculture and coculture period}

Through a series of culture period grads experiments, as shown in Figure 2, the preculture for hypocotyl explants could improve the GUS transient expression efficiency (especially 2 days of preculture: efficiency up to $75.97 \%$ ). The result was similar as previous reports. Reports from SANGWAN et al. (1992) and McHughen et al. (1989) suggested that the preculture was associated with the presence of phytohormones in the medium, which promoted cell division. Moreover, actively dividing cells were involved in delivery and integration of T-DNA. Furthermore, preculture might also reduce the interference of the bacteria or the selection agent on cell differentiation.

The period of coculture can directly affect the transformation efficiency (LÓPEZ et al., 2000). Compared with coculture explants, explants with no coculture period showed a little GUS transient expression efficiency $(14.38 \%)$. As shown in Fig. 2, when we prolonged the coculture time to 2 days, GUS transient expression efficiency increased rapidly, reaching a maximum $(75.97 \%)$. However, coculture periods (more than 2 days) would

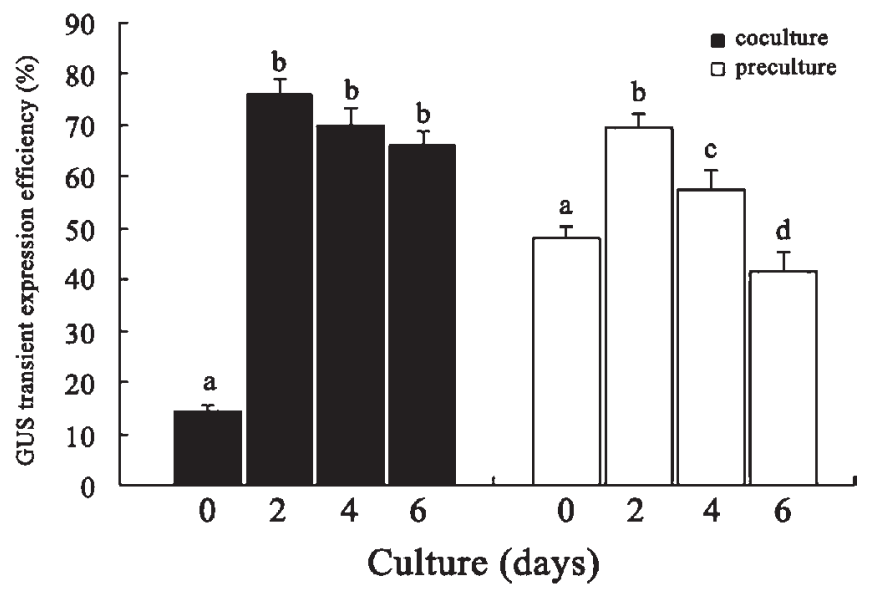

Figure 2. - Effect of coculture and preculture on GUS transient expression efficiency of hypocotyl explants. Bar represents mean \pm standard error of three replicates. The GUS transient expression frequency and positions with different letters above bars were defined as in Fig. 1.

result in decrease in transient GUS transient expression efficiency. The reason might be that the explants, generated with excessive coculture, could result in Agrobacterium overgrowth and subsequent death of explants during selection. Thus, in appropriate coculture period, most calli were kanamycin-resistant, which bring higher transgenic plants.

\section{Forming and selection of transgene calli}

Plant growth regulators are important factors, which can selectively influence the genes triggering differentiation of cells in culture (THORPE, 1983). In previous reports (SUJATHA et al., 1996; LIN et al., 2002; WEI et al., 2004), BA and IBA were shown as effective growth regulators for the induction of calli from hypocotyl explants of $J$. curcas. In our experiment, we used BA $\left(0.1 \mathrm{mg} \cdot \mathrm{l}^{-1}\right.$, $\left.0.5 \mathrm{mg} \cdot \mathrm{l}^{-1}, 1.0 \mathrm{mg} \cdot \mathrm{l}^{-1}\right)$ and IBA $\left(0.1 \mathrm{mg} \cdot \mathrm{l}^{-1}, 0.5 \mathrm{mg} \cdot \mathrm{l}^{-1}\right.$, $\left.1.0 \mathrm{mg} \cdot \mathrm{l}^{-1}\right)$ to determine the most suitable concentrations. From Table 1, we observed that the most efficient inducement $(98 \%)$ for hypocotyl was from $0.5 \mathrm{mg} \cdot \mathrm{l}^{-1} \mathrm{BA}$ and $1.0 \mathrm{mg} \cdot \mathrm{l}^{-1}$ IBA combination. During the inducement, we also observed that increased IBA concentration enhanced the calli inducement, and the influence from change in BA concentration was less obvious than that from change in IBA concentrations. IBA had the main effect and BA had synergetic effect. Thus we used BA $\left(0.5 \mathrm{mg} \cdot \mathrm{l}^{-1}\right)$ and IBA $\left(1.0 \mathrm{mg} \cdot \mathrm{l}^{-1}\right)$ combination to induce transformed hypocotyl calli.

To select the transformants with kanamycin-resistance, hypocotyl explants from untransformed in vitro J. curcas were tested for tolerance to kanamycin. The growth of hypocotyl cultures of J. curcas was rather sensitive to kanamycin. When hypocotyl segments were cultured on MS medium without the addition of kanamycin, calli started to form at the edges of explants after 1 week and proliferated rapidly in the following 3 weeks. However, at kanamycin levels of $40 \mathrm{mg} \cdot \mathrm{l}^{-1}$ and above, the growth of the hypocotyl segment was stopped after only 1 week and necrosis rapidly developed. After 
cocultured with A. tumefaciens, the hypocotyl explants were transferred to selective medium. Calli inducation media with $250 \mathrm{mg} \cdot \mathrm{l}^{-1}$ cefotaxime could not suppress A. tumefaciens overgrowth (data not shown). $500 \mathrm{mg} \cdot \mathrm{l}^{-1}$ cefotaximate and $40 \mathrm{mg} \cdot \mathrm{l}^{-1} \mathrm{kanamycin}$ produce the rate of hypocotyl explants forming resistant calli of $67.08 \%$. In Fig. 3a, small green growing tissues eventually arose from the brownish material kept on selective medium for several weeks. Others that had no target gene became yellow, even brown, finally became necrotic.

Table 1. - The different concentrations of BA and IBA on calli inducation from hypocotyl explants of J. curcas.

\begin{tabular}{cccc}
\hline $\begin{array}{c}\text { Total number of } \\
\text { explants }\end{array}$ & BA & IBA & Inducation number (rate) \\
\cline { 2 - 3 } 100 & 0.1 & 0.1 & of calli $(\%)$ \\
100 & 0.1 & 0.5 & $16(16)$ \\
100 & 0.1 & 1.0 & $68(68)$ \\
100 & 0.5 & 0.1 & $82(82)$ \\
100 & 0.5 & 0.5 & $19(19)$ \\
100 & 0.5 & 1.0 & $77(77)$ \\
100 & 1.0 & 0.1 & $98(98)$ \\
100 & 1.0 & 0.5 & $20(20)$ \\
100 & 1.0 & 1.0 & $82(82)$ \\
\hline
\end{tabular}
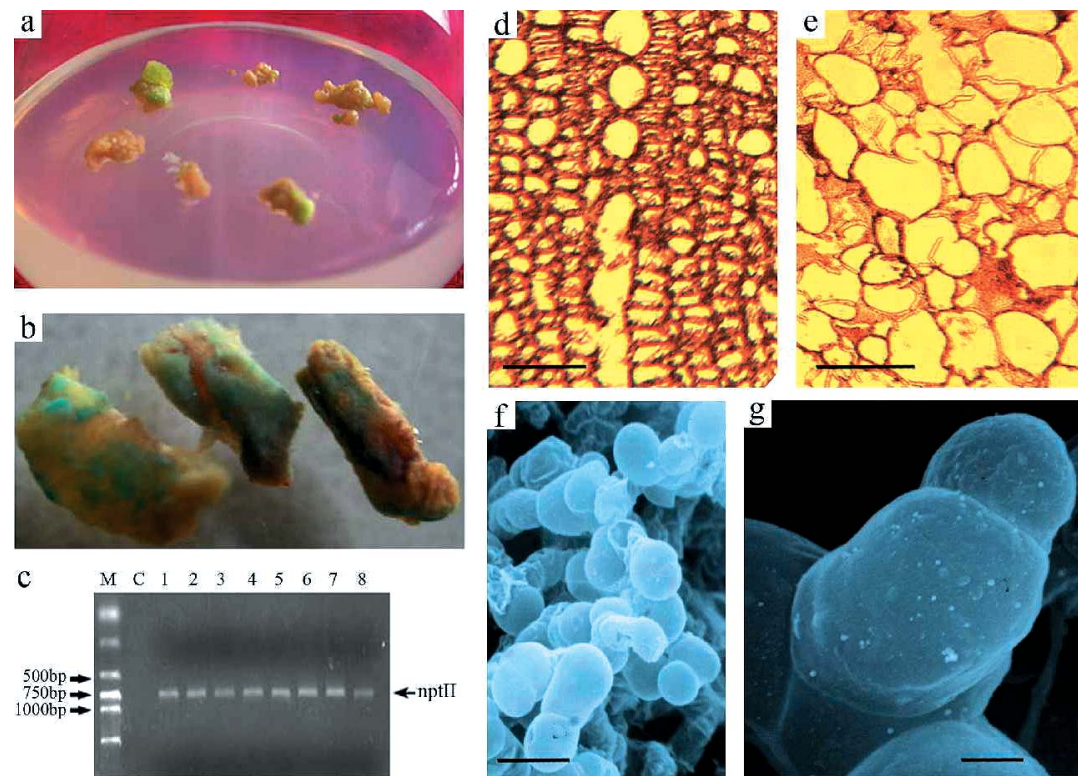

Figure 3. - Selection and morphology analysis of transgenic calli. (a) Selection of putative transformants on kanamycin. (b) Stable GUS expression in transformats calli. (c) Amplification of the NPT II gene in transgenic calli of J. curcas. Lane C: non-transformed control calli; lanes 1-8: transgenic calli; lane M: $2 \mathrm{~kb}$ ladder DNA marker. (d) Cell structure of transformant calli, selected transferred calli cells arrange evenly and tightly (e) Cell structure of non-transformed calli, non-transformed cells show the disorders arrangement. (f) Under 200 times, overview of transformant calli. The protuberance is large and spherical. (g) Under 1000 times, details showing one protuberance. It can be obviously divided into 2 parts; smaller in the top and larger in the below. Bars in $\mathrm{d}, \mathrm{e}=100 \mu \mathrm{m}$.; $\mathrm{f}=50 \mu \mathrm{m} ; \mathrm{g}=15 \mu \mathrm{m}$. 


\section{Analysis of the transformants}

Transformants were demonstrated by GUS assay and PCR analysis. GUS histochemical assay showed that the presence of GUS activity in all putative transgenic calli (Fig. 3b). PCR analysis was carried out as a rapid identification for the presence of the NPTII gene in selected transgenic calli. Fig. $3 c$ showed that a $717 \mathrm{bp}$ fragment was amplified in transformed calli, but not in the nontransformed calli. For avoiding false positive results, virc-specific primers were used for further identification (data not shown), which indicated that no residual A. tumefaciens were present in the analyzed material.

\section{Morphology analysis of transgene calli}

In order to investigate the cell development in transgene calli, morphology analysis of transgene calli was performed. Frozen sections revealed the cells arrangement in calli. As shown in Fig. 3d, selected transformed calli cells arranged evenly and tightly. However, nontransformed calli cells showed the disorder arrangement (Fig. 3e).

SEM revealed the cells from both calli (transformats and untransformats) have certain differences in size and appearance (Fig. 3f). According to observation for calli growth, most of cells are spheroid. However, many samples showed that some protuberances are present at the surface of calli cells. These protuberances are large and spherical, and they can be obviously divided into two parts (Fig. 3g): a smaller part in the top and a larger part in the below. All parts have the trend to grow upward. The functions of protuberances are still unknown. HÄsLER et al. (2003) suggested that these buds sometimes contain an accessory nucleus, which is related to cell division.

\section{Conclusion}

We have shown here, a reliable method for the production of transgenic calli via $A$. tumefaciens-mediated hypocotyl transformation of J. curcas. Some factors that affect the transformation efficiency were optimized, including preculture and coculture periods (2 days), explants source (hypocotyl explants), usage of AS. After infecting with $A$. tumefaciens, the hypocotyl explants were subjected to expansion and proliferation on MS medium with $1.0 \mathrm{mg} \cdot \mathrm{l}^{-1} \mathrm{IBA}$ and $0.5 \mathrm{mg} \cdot \mathrm{l}^{-1} \mathrm{BA}$. Transformants were selected in selective medium. Histochemical GUS assay and PCR analysis proved that putative transgenic calli are stable, the rate of hypocotyl explants forming resistang calli in J. curcas reached $67.08 \%$. Observed by LM and SEM, selected transformed calli cells arranged evenly and tightly. Many protuberances, with large and spherical, are present in calli cells, which may be involved in cell division. This study provides not only an efficient transformation system of J. curcas, but also a fundamental information and new research approach for the future study of inducing new traits to J. curcas and genetic modification.

\section{Acknowledgements}

We are especially grateful to YongJIONG JIA, SHENGHUA WANG, and LIN TANG for their help and invaluable sugges- tions. This work was supported by grants from the national " $11^{\text {th }}$ Five-Year" key scientific and technological project (no. 2006BAD07A04) and the key project of Sichuan Province (no. 2006z07-004-01, no. 05NG002-002-1 and no. 04JY029-080-3).

\section{References}

Godwin, I., G. Todd, B. Ford-Lloyd and H. J. Newbury (1991): The effects of acetosyringone and $\mathrm{pH}$ on Agrobacterium-mediated transformation vary according to plant species. Plant Cell Rep 9: 671-675.

HÄSleR, J., J. WÜEST, T. GASPAR and M. CRÈVECoeur (2003): Long term in vitro-cultured plant cells show typical neoplastic features at the cytological level. Biol Cell 95: 357-364.

Hiei, Y., S. OHta, T. Komari and T. Kumashiro (1994): Efficient transformation of rice (Oryza sative L.) mediated by Agrobacterium and sequence analysis of the boundaries of T-DNA. Plant J 6: 271-282.

Hood, E. E., S. B. Gelvin, L. S. Melchers and A. HoEkeMA (1993): New Agrobacterium helper plasmids for gene transfer to plants. Transgenic Res 2: 208-218.

Hou, P., S. W. Zhang, L. YANG, Y. Xu, L. TANG, S. H. WANG, H. M. TAN and F. CHEN (2006): Callus induction from Jatropha curcas endosperm and elimination of microbial contamination in culture. Chin J Appl Environ Biol 12: 264-268.

Huang, M. X., P. Hou, Q. WeI, Y. Xu and F. Chen (2008): A ribosome-inactivating protein (curcin 2) induced from Jatropha curcas can reduce viral and fungal infection in transgenic tobacco. Plant Growth Regul 54: 115-123.

IshidA, Y., H. SAito, S. OHTA, Y. Hiei, T. Komari and T. KumASHIRo (1996): High efficiency transformation of maize (Zea mays L.) mediated by Agrobacterium tumefaciens. Nat Biotechnol 14: 745-750.

James, D. J., S. Uratsu, J. Cheng, P. Negri, P. Viss and A. M. DANDEKAR (1993): Acetosyringone and osmoprotectants like betaine or praline synergistically enhance Agrobacterium-mediated transformation of apple. Plant Cell Rep 12: 559-563.

Jefferson, R. A., T. A. Kavanagh and M. W. Bevan (1987): Gus fusions: $\beta$-glucuronidase as a sensitive and versatile gene fusion marker in higher plants. EMBO J 6: 3901-3907.

JHA, T. B., P. MukherJeE and M. M. DATTA (2007): Somatic embryogenesis in Jatropha curcas Linn., an important biofuel plant. Plant Biotechnol Rep 1: 135-140.

Li, M. R., H. Q. Li, H. W. JIANG, X. P. PAN and G. J. WU (2008): Establishement of an Agrobacterium-mediated cotyledon disc transformation method for Jatropha curcas. Plant Cell Tiss Org Cult 92: 173-181.

LIN, J., X. W. ZHou, K. X. TANG and F. Chen (2004): A survey of the studies on the resources of Jatropha curcas. J Trop Subtrop Bot 12: 285-290.

LÓPEz, M., J. M. Humara, R. RodRíGuez and R. J. ORDÁs (2000): Factors involved in Agrobacterium tumefaciensmediated gene transfer into Pinus nigra Arn. ssp. salzmannii (Dunal) Franco. Euphytica 114: 195-203.

MAMPANE, K. J., P. H. JoubeRT and I. T. HAY (2006): Jatropha curcas: use as a traditional Tswana medicine and its role as a cause of acute poisoning. Phytother Res 1: $50-51$.

McHughen, A., M. Jordan and G. Feist (1989): A preculture period prior to Agrobacterium inoculation increases production of transgenic plants. J Plant Physiol 135: 245-248. 
Murashige, T. and F. Skoog (1962): A revised medium for rapid growth and bio assays with tobacco tissue cultures. Physiol Plant 15: 473-497.

OpENSHAW, K. (2000): A review of Jatropha curcas: an oil plant of unfulfilled promise. Biom Bioenerg 19: 1-15.

RAJORE, S. and A. BATRA (2005): Efficient plant regeneration via shoot tip explant in Jatropha curcas L. J. Plant Biochem Biotech 14: 73-75.

SAmbrook, J., E. F. Fritsch and T. MANiatis (1989): Molecular Cloning: A Laboratory Manual. $2^{\text {nd }}$ edn. Cold Spring Harbor Laboratory Press, Cold Spring Harbor, New York.

Saghai-Maroof, M. A., K. M. Soliman, R. A. Jorgensen and R. W. ALLARD (1984): Ribosomal DNA spacer-length polymorphisms in barley: Mendelian inheritance, chromosomal location, and population dynamics. Proc Natl Acad Sci USA 81: 8014-8018.

SAngwan, R. S., Y. Bourgeois, S. Brown, G. Vasseur and B. SANGWAN-NorReEl (1992): Characterization of competent cells and early events of Agrobacterium-mediated genetic transformation in Arabidopsis thaliana. Planta 188: 439-456.

SARDANA, J., A. BATRA and D. J. Ali (2000): An expeditious method for regeneration of somatic embryos in Jatropha curcas L. Phytomorphology 50: 239-242.
Schmook, B. and L. Serralta-PerazA (1997): Jatropha curcas: distribution and uses in the Yucatan peninsula of Mexico. In: GÜBITZ G. M., M. MitTelbaCH and M. TRABI (eds) Biofuels and industrial products from Jatropha curcas. pp 53-57.

Sharma, K. K., P. Bhatnagar-Mathur and T. A. Thorpe (2005): Genetic transformation technology: status and problems. In Vitro Cell Dev Biol-Plant 41: 102-112.

Shrivastava, S. and M. BANERJEe (2008): In vitro clonal propagation of physic nut (Jatropha curcas L.): Influence of additives. Int $J$ of Integr Biol 3: 73-79.

Staubmann, R., I. Ncube, G. M. Gübitz, W. Steiner and J. S. READ (1999): Esterase and lipase activity in Jatropha curcas L. J Biotechnol 75: 117-126.

SujATHA, M. and N. MuKTA (1996): Morphogenesis and plant regeneration from tissue cultures of Jatropha curcas. Plant Cell Tiss Org Cult 44: 135-141.

SUJATha, M., H. P. S. MAKKAR and K. Becker (2005): Shoot bud proliferation from axillary nodes and leaf sections of non-toxic Jatropha curcas L. Plant Growth Regul 47: 83-90.

THORPE, T. A. (1983): Morphologenesis and regeneration in tissue culture. Beltsville Sym Agr Res 7: 285-303.

Wei, Q., W. D. Lu, Y. LiaO, S. L. PAN, Y. Xu, L. TANG and F. CHEN (2004): Plant regeneration from epicotyl explants of Jatropha curcas. J Plant Physiol Mol Biol 30: $475-478$. 